\title{
Primeiros resultados do Censo Demográfico 2010
}

Neste primeiro semestre de 2011, o IBGE está iniciando a divulgação dos dados definitivos do Censo Demográfico de 2010.

No dia 29 de abril foram apresentados os resultados da chamada Sinopse do Censo Demográfico 2010, a qual, além de oferecer um painel ilustrativo sobre a evolução demográfica do país desde o I Recenseamento Geral em 1872, divulga os dados definitivos sobre a população por sexo e idade, a média de moradores em domicílios particulares ocupados e o número de domicílios recenseados, segundo a espécie e a situação urbano e rural.

Trata-se de um conjunto inicial fundamental para que o público interessado, os formuladores de políticas, os planejadores e, sobretudo, os estudiosos de população disponham dos primeiros instrumentos de avaliação da composição e tendências da população brasileira e de sua distribuição pelos entes federativos, no limiar da segunda década do século atual.

O Censo Demográfico 2010 consolidou a utilização de inovações tecnológicas, metodológicas e gerenciais, consubstanciadas no uso do computador de mão equipado com GPS para coleta das informações, na informatização de aproximadamente 7.000 postos de coleta espalhados pelo território nacional, na introdução das rotinas de crítica no próprio processo de preenchimento dos questionários, enfim, em um conjunto ágil e integrado de procedimentos que asseguraram maior qualidade e controle na operação de coleta e no ritmo posterior da apuração dos resultados.

Os primeiros resultados definitivos que constam na Sinopse 2010 permitem algumas reflexões exploratórias sobre o comportamento e a evolução recente da população brasileira, dos Estados e dos 5.565 municípios.

Os números oficiais divulgados confirmam as avaliações dos estudiosos sobre a continuidade do ritmo de desaceleração do crescimento populacional no país. Rompendo a barreira dos 190 milhões de habitantes em 2010, o Brasil apresentou, nessa primeira década do século $\mathrm{XXI}$, em comparação aos períodos censitários, a mais baixa taxa de crescimento anual de toda a série: $1,17 \%$ ao ano.

A análise das tendências demográficas recentes certamente deverá merecer atenção dos demógrafos, mas, somente quando for divulgado o total das variáveis demográficas investigadas, será viável, em termos do rigor técnico e metodológico, estabelecer com mais garantia e precisão os parâmetros e tendências da dinâmica demográfica do país e de seus entes federativos.

Desse modo, são aguardados para divulgação, no início de 2012, os primeiros resultados definitivos do questionário da amostra, quando estarão disponíveis, entre outras, as informações relativas às componentes demográficas.

Em sintonia com a continuidade da desaceleração do crescimento demográfico, fruto principalmente do processo de declínio dos níveis de fecundidade, a composição da população por sexo e idade, em 2010, revela, em relação aos Censos de 1991 e 2000, acentuado estreitamento da base da pirâmide, inclusive com redução do número absoluto de crianças entre 2000 e 2010. Simultaneamente, percebe-se o alargamento do ápice da pirâmide, com o aumento expressivo da população de 60 anos e mais. É a combinação do decréscimo dos níveis de fecundidade com a queda da mortalidade no período que naturalmente determina tais movimentos. 
A análise da evolução da estrutura etária vislumbrada nos resultados censitários, quando contextualizada a partir das tendências esperadas da mortalidade e fecundidade, disporá de novos caminhos e indicativos para avaliação do processo de envelhecimento, bem como de novas luzes para as revisões das projeções populacionais para as próximas décadas, por sexo e idade.

Outro aspecto que se deve destacar nesses primeiros resultados refere-se ao comportamento do crescimento populacional nas Grandes Regiões, nos Estados e, de forma também muito peculiar, nos municípios brasileiros conforme o porte populacional.

As maiores taxas de crescimento populacional, de maneira semelhante ao que vem ocorrendo nas últimas décadas, foram registradas no Norte e Centro Oeste, onde inclusive se localizam os dez Estados com maior aumento relativo. Nas outras Regiões (Nordeste, Sudeste e Sul), a taxa mais elevada foi a de Santa Catarina, área de destino de determinados fluxos migratórios do Sul e Sudeste. As Regiões Sudeste e Nordeste registraram taxas bastante próximas, em torno de $1 \%$ ao ano, revelando queda do ritmo de crescimento de várias áreas metropolitanas e a própria redução do aumento natural da população. Interessante observar a baixa taxa de crescimento demográfico do Rio Grande do Sul, fruto provavelmente de saldos migratórios negativos e de uma reduzida taxa de crescimento vegetativo, em função da baixa fecundidade e da estrutura etária mais envelhecida.

No que toca ao comportamento urbano e municipal, é importante ressaltar, em primeiro lugar, que o grau de urbanização aumentou de $81,2 \%$, em 2000 , para $84,4 \%$, em 2010 . As duas regiões de menor grau de urbanização, Norte e Nordeste, já apresentam uma população urbana acima de $73 \%$ do total.

Quanto ao porte dos municípios, as maiores taxas de crescimento médio foram observadas naqueles com 100 mil a 500 mil habitantes, em torno de 2,05\% ao ano, contra $1,79 \%$ para os municípios com mais de 500 mil habitantes. Aqueles com menos de dez mil habitantes, que reúnem mais de 2.500 municípios, apresentaram crescimento médio negativo.

Portanto, são os municípios de porte médio, caracterizados como núcleos polarizadores de importantes sub-regiões da maioria dos Estados brasileiros, que mais tendem a atrair populações e oportunidades de crescimento a nível regional.

Em suma, os resultados da Sinopse do Censo Demográfico 2010 permitem a construção de amplos painéis sobre a evolução demográfica de nosso país. Além disso, a publicação está acompanhada por um CD-ROM que contém um conjunto de 21 tabelas com alguns resultados preliminares de variáveis do questionário básico do Censo, como cor ou raça, condição no domicílio, pessoas responsáveis pelo domicílio, pessoas com registro de nascimento em cartório, alfabetização, rendimento domiciliar e características dos domicílios. Ao longo dos próximos meses, estão previstas várias outras divulgações dos resultados censitários.

Em relação aos artigos que estão sendo publicados neste número da Rebep, é interessante salientar a diversificação do alcance da Revista, com uma ampliação do leque de autores das diversas regiões do país.

Embora ainda haja uma concentração de autores provenientes do Sudeste (neste número existe uma importante contribuição de Minas Gerais), observa-se a presença de autores das Regiões Norte (Amazonas), Nordeste (Bahia) e Sul (Paraná).

É importante também ressaltar que a Rebep tem publicado, continuamente, textos de autores do exterior. Neste número, entre os artigos, temos um representante de Moçambique e outro da Universidade de Wisconsin. Na nota técnica, conta-se com a participação de dois autores da Universidade de Brown e, nas resenhas, de uma doutoranda da Califórnia, Berkely.

Luiz Antonio Pinto de Oliveira

Coordenador de População e Indicadores Sociais, IBGE 